\title{
Membentuk Karakter Enterperneurship untuk Mahasiswa dalam Mata Kuliah Kewirausahaan
}

\author{
Khurin'In Ratnasari \\ IAI Al-Falah As-sunniyyah Kencong \\ Kencong, Kamaran, Jember, Jawa Timur \\ khurininratnsari@gmail.com
}

\begin{abstract}
Abstrak- Di Indonesia tingkat pengangguran terus mengalami kenaikan. Terutama jumlah lulusan mahasiswa yang semakin hari semakin banyak. Dalam data BPS tahun 2017 di lansir dari depok pos permasalahan utama pembangunan ekonomi di Indonesia adalah tingginya angka pengangguran dan lambatnya pertumbuhan ekonomi Indonesia. Tercatat pada bulan November 2017 saja, tingkat pengangguran di Indonesia mencapai 5,50\% sedangkan pertumbuhan ekonomi pada tahun ini atau di triwulan ke III tumbuh sebesar 5,03\% jumlah tersebut telah naik dari tahun 2014 sebesar 4,79\% yang mana itu merupakan presentase terendah dari 6 tahun terakhir. Peran perguruan tinggi sangat penting dalam membangun karakter generasi bangsa. Salah satu hal yang dapat ditawarkan sebagai solusi efektif adalah membentuk mahasiswa yang berkarakter entrepreneur. Hal ini penting karena dapat secara efektif mengurangi tingkat lulusan pencari kerja sekaligus meningkatkan lulusan pencetak kerja; dan dapat berkontribusi terhadap kemakmuran bangsa. Karakter entrepreneur yang diharapkan adalah karakter yang bisa mencetak usaha produktif dan inovatif. Entrepreneur yang secara konsisten selalu kreatif dan inovatif dalam melihat danmenciptakan peluang, serta mampu merealisasikan peluang itu menjadi sesuatu yang lebih berharga di bidang agraris, bidang perikanan, bidang perindustrian, bidang peternakan dan bidang jasa.
\end{abstract}

Kata Kunci- Entrepreneur, Karakter Entrepreneur, Mahasiswa

Abstract- The unemployment rate in Indonesia continues to increase. This is one of the main problems of economic development in Indonesia. According to BPS data, in November 2017, the unemployment rate in Indonesia reached 5.50\% while economic growth in the third quarter of the same year was $5.03 \%$, an increase from $4.79 \%$ in 2014 which is the lowest growth in the last six years. Higher education institutions (HEIs) play an important role in building national characters including the entrepreneurship character, which can be an answer to the question of unemployment. In this respect, HEIs are expected to contribute to bring about productive and innovative entrepreneurs who can seize opportunities in various fields such as agriculture, fishery, industry, farming, and services.

Keyword: Entrepreneurship character, University Students

\section{PENDAHULUAN}

Pembangunan ekonomi membutuhkan Sumber Daya Manusia. Pembentukan sumber daya manusia sangat diperlukan agar proses produktivitas SDM sesuai dengan apa yang diharapkan, Namun, kelebihan kuantitas SDM di Indonesia mendorong pemerintah tidak hanya mengarahkan penduduk menjadi tenaga kerja atau karyawan, tetapi juga menjadi penyedia lapangan pekerjaan. Penumbuhan minat kewirausahaanmenjadi penting dalam pembangunan ekonomi mengingat kondisi kontras antara demand dan supply tenaga kerja. Penawaran tenaga kerja sangat tinggi sedangkan permintaannya relatif rendah. Dalam data BPS tahun 2017 di lansir dari depok pos permasalahan utama pembangunan ekonomi di Indonesia adalah tingginya angka pengangguran dan lambatnya pertumbuhan ekonomi Indonesia. Tercatat pada bulan November 2017 saja, tingkat pengangguran di Indonesia mencapai 5,50\% sedangkan pertumbuhan ekonomi pada tahun ini atau di triwulan ke III tumbuh sebesar $5,03 \%$ jumlah tersebut telah naik dari tahun 2014 sebesar 4,79\% yang mana itu merupakan presentase terendah dari 6 tahun terakhir. Besarnya pengangguran ini tentunya akan membawa konsekuensi pada dirinya sendiri, keluarga, sosial kemasyarakatan dan bangsa. Mari kita lihat pendapat pakar berkaitan dengan hal tersebut terutama bidang usaha. David McClelland menyebutkan bahwa suatu negara akan menjadi makmur minimal jumlah entrepreneur (pengusaha) negara tersebut sebesar 2\% dari total penduduknya. Amerika Serikat pada tahun 2007 mempunyai $11,5 \%$ entrepreneur. Singapura mempunyai $7,2 \%$ entrepreneur pada tahun 2005 . Sedangkan Indonesia pada tahun 2007 hanya mempunyai $0,18 \%$ atau sebesar 400.000 entrepreneur padahal yang seharusnya 4,4 juta entrepreneur. Kemudian ada pendapat menarik dari Lester Thurow, seorang profesor ekonomi dan manajemen dari MIT, yang menyatakan tanpa entrepreneur maka ekonomi menjadi miskin dan lemah.

Dari penjelasan diatas menerangkan bahwa besarnya pengangguran dan pentingnya entrepreneur. Maka sudah selayaknyalah kita sebagai pendidik di dunia pendidikan mulai berorientasi secara sungguhsungguh dalam mendidik mahasiswa kita untuk mempunyai karakter seorang entrepreneur.Perguruan 
tinggi juga ikut mendukung secara aktif program program usaha yang produktif di kalangan mahasiswa, dengan kata lain mahasiswa pun dituntut untuk ikut andil dalam pertumbuhan ekonomi di Indonesia dengan membentuk kelompok usaha dan menggiatkan pengembangan entrepreneurship tingkat mahasiswa. Dan menerapkan strategi mikro dan makro dalam kurikulum ataupun pelatihan dalam perguruan tinggi. Sehingga besarnya pengangguran dapat diminimalisasi dan sekaligus berperan dalam memakmurkan bangsa. Berdasarkan paparan diatas maka, dalam artikel ini, penulis akan akan menyoroti pentingnya pembentukan karakter entrepreneur untuk mahasiswa (kewirausahaan).

\section{KAJIAN PUSTAKA}

Pengertian Entrepreneurship berasal dari Bahasa Perancis, yakni entreprendre yang berarti melakukan (to under take), dalam arti melakukan kegiatan mengorganisir dan mengatur. Istilah ini diperkenalkan pertama kali oleh Richard Cantillon pada tahun 1755 dalam tulisannya Essai Sur la Nature du Commerce en General. Pada masa itu istilah entrepreneur merupakan sebutan bagi para pedagang yang membeli barang di daerah-daerah dan kemudian menjualnya dengan harga yangtidak pasti. Dalam literatur-literatur kewirausahaan, entrepreneurship diartikan berbeda-beda oleh para ahli. Menurut Suryana, entrepreneurship

merupakan suatu proses penerapan kreativitas dan inovasi untuk memecahkan dan mencari peluang dari masalah yang dihadapi oleh setiap orang dalam kehidupan sehari-hari. Berdasarkan definisi ini, inti dari entrepreneurship adalah kreativitas dan inovasi. Kreativitas adalah kemampuan untuk membuat ide baru dengan mengkombinasikan, mengubah, atau merekonstruksi ide-ide lama.Sedangkan inovasi merupakan penerapan dari penemuan suatu proses produksi baru atau pengenalan akan suatu produk baru.

Danang Sunyoto memiliki pandangan berbeda. Menurutnya, entrepreneurship adalah suatu sikap untuk menciptakan sesuatu yang baru serta bernilai bagi diri sendiri dan orang lain. Menurut definisi ini, entrepreneurship tidak hanya tentang mencari keuntungan pribadi, namun juga harus mempunyai nilai sosial. Definisi berbeda diungkap oleh Abu Marlo, menurutnya entrepreneurship adalah kemampuan seseorang untuk peka terhadap peluang dan memanfaatkan peluang tersebut untuk melakukan perubahan dari sistem yang ada. Dalam dunia entrepreneurship, peluang adalah kesempatan untuk mewujudkan atau melaksanakan suatu usaha dengan tetap memperhitungkan resiko yang dihadapi.
Ada juga definisi yang lebih ringkas sebagaimana dikemukakan oleh Kasmir. Menurutnya, entrepreneurship merupakan kemampuan dalam menciptakan sesuatu yang baru dan berbeda. Pengertian ini mengandung maksud bahwa seorang entrepreneur adalah orang yang memiliki kemampuan untuk menciptakan sesuatu yang belum pernah ada sebelumnya, atau bisa juga dengan menciptakan sesuatu yang berbeda dari Karakteristik Entrepreneur Dalam pembahasan sebelumnya diketahui bahwa entrepreneurship merupakan suatu proses yang dilakukan oleh seorang entrepreneur dalam menerapkan kreativitas dan inovasi guna mewujudkan peluang dalam bisnis. Proses tersebut pada dasarnya merupakan implementasi dari karakteristikkarakteristik yang melekat pada diri entrepreneur. Karakteristik ini sekaligus menjadikannya berbeda dengan pebisnis biasa. Meski demikian, para ahli mempunyai pandangan yang berbeda. Manurut Winardi ada 8 karakteristik entrepreneur, yakni:

a. Desire for responsibility, yaitu memiliki rasa tanggung jawab atas usaha-usaha yang dilakukannya. Seseorang yang memiliki tanggung jawab akan selalu mawas diri.

b. Preference for moderate risk, yaitu lebih memilih resiko yang moderat, artinya selalu memiliki keberanian untuk mengambil resiko selama masih ada peluang untuk berhasil.

c. Confidence in their ability to success, yaitu memiliki kepercayaan diri untuk memperoleh kesuksesan.

d. Desire for immediate feedback, yaitu selalu menghendaki umpan balikdengan segera.

e. High level of energy, yaitu memiliki semangat dan kerja keras untuk mewujudkan keinginannya demi masa depan yang lebih baik.

f. Future orientation, yaitu berorientasi serta memiliki perspektif dan wawasan jauh ke depan.

g. Skill at organizing, memiliki keterampilan dalam mengorganisasikan sumber daya untuk menciptakan nilai tambah. Value of achievement over money, lebih menghargai prestasi dari pada uang

Sedangkan menurut Agbim, sebagaimana dikutip Agung Wahyu,

hanya ada 6 karakteristik entrepreneur, yaitu:

a. Tidak mudah menyerah dalam mencapai tujuan (need for achievement)

b. Sikap entrepreneur dalam mengelola usahanya (locus of control). 
c. Memilih suatu tantangan namun cukup kemungkinan untuk berhasil (risk taking propensity).

d. Kemampuan unutuk berhubungan dengan sesuatu yang tidak bisa diprediksi (tolerence for ambiguity).

e. Dapat menciptakan barang dan jasa baru (innovativeness)

f. Memiliki percaya diri yang tinggi akan keberhasilan usahanya (confidence).

Menurut Danang Sunyoto seorang entrepreneur memiliki beberapa

karakteristik, yakni:

a. Disiplin, yaitu usaha untuk mengatur atau mengontrol kelakuan seseorang guna mencapai suatu tujuan dengan adanya bentuk kelakuan yang harus dicapai, dilarang, atau diharuskan.

b. Mandiri, yaitu sikap untuk tidak menggantungkan keputusan akan apa yang harus dilakukan kepada orang lain dan mengerjakan sesuatu dengan kemampuan sendiri sekaligus berani mengambil resiko atas tindakanya tersebut.

c. Realistis, yaitu cara berpikir yang sesuai dengan kenyataan.

d. Komitmen tinggi, yaitu mengarahkan fokus pikiran pada tugas dan usahanya dengan selalu berupaya untuk memperoleh hasil yang maksimal.

e. Jujur, yaitu mau dan mampu mengatakan sesuatu sebagaimana adanya. yang ada Kreatif dan inovatif, yaitu proses pemikiran yang membantu dalam mencetuskan gagasan-gagasan baru serta menerapkannya dalam usaha bisnis yang nyata.

Berbeda dengan ketiga pendapat di atas, Abdul Jalil menyatakan bahwa ada 4 unsur karakter yang melekat dalam diri seorang entrepreneur yaitu:

\section{a. Aktif}

Seorang entrepreneur merupakan pribadi yang aktif dalam berbagaikegiatan ekonomi dan bisnis. Pantang baginya untuk bermalas-malasan.Ia akan selalu aktif mengidentifikasi peluang-peluang yang ada di pasar untuk dijadikan sebagai acuan dalam mengembangkan bisnisnya.

b. Produktif

Entrepreneur adalah sosok yang produktif dalam hidupnya. Produktif ini erat kaitannya dengan manajemen waktu, energi, dan fokus. Seorang entrepreneur akan selalu memberikan hasil maksimal dengan mengoptimalkan ketiga hal tersebut.

c. Inovatif

Ini merupakan karakter vital dari seorang entrepreneur. Dengan karakter inovatif ini, seorang entrepreneur selalu menghadirkan perubahan-perubahan yang baru dan jitu dalam dunia bisnis, baik berupa bahan baku baru, proses baru, ataupun pasar baru.

d. Kalkulatif

Seorang entrepreneur bukanlah orang yang sembarangan dalam mengeksekusi peluang bisnis. Setiap keputusan dan langkah yang diambil tidak lain merupakan hasil kalkulasi yang matang.Dari semua pendapat di atas, rumusan karakteristik yang disampaikan terakhir dinilai sebagai yang paling relevan. Selain ringkas, rumusan tersebut sejalan dengan pengertian entrepreneur yang disampaikan di awal.

Ruang Lingkup Entrepreneurship Berbagai karakteristik dari seorang entrepreneur dalam bahasan sebelumnya jika diperhatikan merupakan sifat-sifat umum yang bisa melekat pada siapa pun, tidak terbatas pada pedagang saja. Oleh karena itu, dalam beberapa literatur para ahli memberikan pemetaaan tentang ruang lingkup entrepreneurship dengan sangat luas dan mencakup berbagai bidang, yaitu:

a. Bidang agraris

Entrepreneur yang aktif di bidang ini biasa dikenal dengan istilah agropreneur. Bidang ini meliputi: pertanian, perkebunan serta kehutanan. Kagiatannya berupa usaha pembibitan, budidaya, serta

kegiatan pasca panen seperti: distribusi, pengolahan, dan pemasaran.

b. Bidang perikanan,

Merupakan salah satu kegiatan bisnis yang dilakukan oleh seseorang maupun perusahaan yang berhubungan dengan pemanfaatan serta pengelolaan sumber daya hayati yang berhabitat di perairan. Pada awalnya, perikanan hanya terbatas pada penyediaan pangan bagi manusia, namun bisnis ini terus berkembang dan merambah sebagai sarana rekreasi, hiburan, dan olahraga.

c. Bidang peternakan.

Peternakan adalah usaha membudidayakan dan mengembangbiakkan hewan ternak dengan maksud mendapatkan manfaat serta hasil dari kegiatan tersebut. Pada masa kini, peternakan sudah menjadi salah satu lahan bisnis prosepektif terbesar di dunia. Hal tersebut didukung dengan berbagai macam teknologi yang dikembangkan secara mutakhir untuk memperoleh hasil maksimal dalam berternak.

d. Bidang perindustrian 
Ini adalah lingkup bisnis yang bergerak di bidang pengolahan bahan mentah atau barang setengah jadi menjadi barang jadi yang memiliki nilai tambah untuk mendapatkan keuntungan. Usaha perakitan atau assembling dan juga reparasi adalah bagian dari industri Bidang pertambangan Merupakan usaha bisnis dalam rangka pemanfaatan hasil bumi berupa mineral atau batubara yang meliputi tahapan kegiatan penyelidikan umum, eksplorasi, studi kelayakan, konstruksi, penambangan, pengolahan dan pemurnian, pengangkutan dan penjualan, serta pasca tambang.

e. Bidang jasa

Ini merupakan bidang bisnis yang menyediakan atau menjual sistem pelayanan kepada konsumen untuk mendapatkan keuntungan. Bidang ini banyak digemari oleh masyarakat. Yang termasuk dalam bidang ini di antaranya adalah penyediaan jasa transformasi, travel, perhotelan, koperasi, dan lain-lain.

Dari berbagai ruang lingkup di atas, dapat disimpulkan bahwa entrepreneurship mencakup hampir semua bidang yang ada dalam bisnis. Hal ini meluruskan pemahaman sebagian masyarakat yang menganggap bahwa entrepreneurship terbatas pada bidang perdagangan saja. Padahal tidak demikian. Memang pada awalnya entrepreneurship adalah sebutan untuk orang yang melakukan transaksi jual beli, namun istilah tersebut terus mengalami perkembangan makna sehingga masuk dalam berbagai bidang sebagaimana disebutkan di atas.

Upaya yang dapatdilakukan oleh perguruan tinggi adalah dengan membentuk karakter entrepreneur mahasiswa. Upaya ini terangkum dalam strategi makro dan mikro. Strategi makro berada pada tataran kebijakan perguruan tinggi dan Strategi mikro berada pada tataran pembelajaran di kelas. Ciputra (2009), dalam bukunya Entrepreneurship Mengubah Masa Depan Bangsa dan Masa Depan Anda, mengungkapkan 3 (tiga) gagasan yang disebut dengan Lompatan Quantum yang dapat digunakan sebagai strategi membentuk entrepreneur. Dengan mengadopsi gagasan tersebut pada tataran perguruan tinggi maka strategi makro yang dapat dilakukan perguruan tinggi dalam mencetak entrepreneur adalah sebagi berikut:

a. Pertama, mengintegrasikan pembelajaran entrepreneurship ke dalam kurikulum perguruan tinggi. b. Kedua, mengembangkan entrepreneurship center pada perguruan tinggi.

c. Ketiga, menciptakan gerakan budaya dan pelatihan entrepreneurship bagi masyarakat.

Berkaca dari data yang telah disebutkan pada awal tulisan ini, maka perguruan tinggi sebagai pencetak lulusan terdidik sekaligus penyumbang pengangguran terdidik harus menata ulang teknologi pembelajarannya pada semua pembelajaran terutama pembelajaran entrepreneurship sehingga dapat membentuk mahasiswa yang mempunyai karakter seorang entrepreneur modern yang sejati. Penataan ulang ini terangkum dalam strategi mikro yang berada pada tataran pembelajaran di kelas terutama pembelajaran entrepreneurship. Pembelajaran entrepreneurship seharusnya adalah:

a. Pembelajaran entrepreneurship adalah pembelajaran yang membentuk manusia secara holistik. Oleh karenanya pembelajaran harus benar-benar meliputi pembentukan kognitif, afektif dan psikomotorik mahasiswa.

b. Pembelajaran entrepreneurship harus didisain sedemikian rupa sehingga dapat membangkitkan kelima panca indera mahasiswa sehingga mahasiswa dapat menerima pembelajaran dengan lebih mudah dan dapat mengesan lebih lama dalam diri mahasiswa. Metode yang dipilih tidak hanya ceramah dan diskusi namun juga harus menggunakan multimedia, simulasi, dan role play.

c. Pembelajaran entrepreneurship adalah experiential learning. Experiential learning mahasiswa dapat belajar langsung dari sebuah pengalaman berentrepreneur yang telah dirancang berdasarkan sasaran pembelajaran. Untuk dapat memberikan pengalaman yang terstruktur kepada mahasiswa maka metode pembelajaran project base learning dapat digunakan.

d. Pembelajaran entrepreneurship merupakan pembelajaran yang real-life sehingga membantu mahasiswa memahami kondisi sesungguhnya dalam dunia entrepreneur.

e. Pembelajaran entrepreneurship harus mampu membentuk karakter seorang entrepreneur. Karakter entrepreneur ini dapat diformulasikan berdasar pendapat para ahli atau karakter yang ditentukan dosen berdasarkan penelitiannya. Karakter yang dapat dibangun melalui pembelajaran seperti semangat (passion), kemandirian (independent), kepekaan pasar (market sensitivity), kreatif dan inovatif (creative and innovative), pengambilan resiko terhitung (calculated risk taking), daya tahan (persistent), 
serta standar etika (ethical standard). Pembentukan karakter ini dapat melalui pembelajaran berbasis life skill.

f. Pembelajaran entrepreneurship tidak sama dengan Business Plan. Business Plan hanyalah mewakili sebagian kecil dari

\section{METODE PENELITIAN}

Jenis Penelitian ini yaitu penelitian kualitatif dengan rancangan Etnografi. Menurut (Harsono, 2016), "Etnografi adalah uraian dan penafsiran suatu budaya atau sistem kelompok sosial. Peneliti menguji kelompok tersebut dan mempelajari pola perilaku, kebiasaan, dan cara hidup. Etnografi adalah sebuah proses dan hasil dari sebuah penelitian. Sebagai proses, entnografi melibatkan pengamatan tersebut peneliti terlibat dalam keseharian hidup responden atau melalui wawancara satu per satu dengan anggota kelompok lain". Tempat penelitian mahasiswa Pendidikan Agama Islam Al-Falah Assuniyah Kencong angkatan 2018 yang telah menempuh mata kuliah Praktek Kewirausahaan. Selanjutnya Narasumber lain yaitu dosen pengampu mata kuliah Praktek Kewirausahaan. Teknik pengumpulan data yang digunakan meliputi teknik wawancara mendalam, observasi, dan dokumentasi (Sugiyono, 2017). Teknik analisis pengumpulan data tentang karakter entrepreneurship dalam mata kuliah Praktek Kewirausahaan, reduksi data, penyajian data dan kesimpulan (Moloeng, 2013).

\section{HASIL DAN PEMBAHASAN}

Kegiatan pembentukkan karakter Entrepreneurship dalam mata kuliah Kewirausahaan dirasa cukup optimal untuk membentuk karakter kewirausahaan karena dalam pelaksanaan kegiatan praktek kewirausahaan hanya berlangsung 2 kali bazar saja, tetapi tidak menutup kemungkinan dengan minimnya praktek yang diberikan kepada mahasiswa walaupun hanya 2 kali pelaksanaan bazar yang berbeda-beda tempat yang bisa membuat mahasiswa memiliki pengalaman yang berdesa setiap tempatnya. Disinilah karakter berwirausaha dapat terbentuk yaitu mahasiswa menjadi percaya diri dalam menjalankan praktek kewirausahaan percaya diri mengantarkan usaha berjalan lancar dan mendapatkan hasil yang memuaskan. Dan mahasiswa juga bisa mengeluarkan ide - de yang kreatif untuk menciptakan peluang usaha. Dengan mengikuti kegiatan e bazar atau expo mahasiswa memiliki karakter inovatif yang membuat mahasiswa menjadi percaya diri untuk melanjutkan usaha yang sedang dijalankannya dengan begitu mahasiswa memiliki motif berprestasi untuk menjalankan usaha dan diseriusi kembali. Karakter berani mengambil resiko sebagian mahasiswa ada yang berani mengambil resiko karena jika tidak berani mengambil resiko berarti usaha tersebut dikatakan gagal, tetapi ada mahasiswa 4 juga yang tidak berani mengambil resiko dengan alasan tidak dapat keluar dari zona amannya jadi mereka membuat produk yang aman dan di senangi masyarakat tidak berani mengambil resiko membuat produk yang baru yang belum tentu di gemari masyarakat. Mengacu pada penelitian sebelumnya yang dilakukan oleh Eni Jamilah (2017) yang berjudul "Pendidikan Kewirausahaan sebagai media pembentukkan karakter santri (studi kasus di Pondok Modern Sumberdaya ATTaqwa Tanjunganom Nganjuk)". Hasil dari penelitian ini yaitu keberhasilan pendidikan kewirausahaan sebagai media pembentuk karakter santri yaitu terciptanya komunikasi dalam kerjasama dan tanggungjawab dalam pengadaan expo,bazar dll. Terciptanya kejujuran dan kedisiplinan saat mengambil konsekwensi dari pelanggaran yang dilakukan. Berdasarkan penelitian tersebut perbedaan dari hasil penelitian yaitu kendala yang dihadapi mahasiswa dalam kerjasama kelompok (team work) salah satunya terdapat mahasiswa yang masih memiliki keraguan dan kepercayaan dengan anggota kelompoknya sehingga mengurangi rasa optimis dalam menjalankan suatu usaha. Persamaan dari hasil penelitian sebelumnya yaitu berani mengambil resiko atau konsekwensi dari kegiatan praktek kewirausahaan.

Pengaruh Mata Kuliah Praktek Kewirausahaan terhadap Pembentukkan Karakter Entrepreneurship Mahasiswa mata kuliah sangat penting untuk mahasiswa karena dibalik mata kuliah yang cukup rumit karena harus ada rancangan bisnis sebelum ada usaha, uji coba produk sebelum dijual dan penjualan produk, semua tugas tersebut akan menjadi peluang apabila mahasiswa dapat menyerap ilmu-ilmu tersebut. Dan dapat diaplikasikan dalam kehidupan sehari - hari. Praktek Kewirausahaan dapat menjadi bekal dalam menjadi seorang wirausaha dan juga salah satu solusi dalam mengurangi pengangguran karena dengan berwirausaha dapat menciptakan lapangan pekerjaan. Mengacu pada penelitian sebelumnya yang dilakukan oleh Moh. Chairil Asmawan (2017) yang berjudul "Dampak Mata Kuliah Praktek Kewirausahaan terhadap Motivasi Mahasiswa Pendidikan Akuntansi untuk berwirausaha" yaitu Setelah melakukan praktek kewirausahaan yang diselenggarakan oleh program studi pendidikan akuntansi pada umumnya mahasiswa telah memiliki keberanian dan kepercayaan dirinya 
semakin bertambah, semakin yakin dan kuat untuk terjun dalam dunia kewirausahaan. Berdasarkan penelitian tersebut dapat dibandingkan dengan hasil yang hamper serupa yaitu dengan adanya Praktek Kewirausahaan mahasiswa memiliki bekal menjadi seorang wirausaha untuk terjun dalam dunia

\section{KESIMPULAN DAN SARAN}

Dalam era globalisasi yang semakin maju ini penting generasi bangsa mempunyai pendidikan karakter entrepreneur maka sudah selayaknya di dunia pendidikan mulai berorientasi secara sungguhsungguh dalam mendidik mahasiswa kita untuk mempunyai karakter seorang entrepreneur sehingga besarnya pengangguran dapat diminimalisasi dan sekaligus berperan dalam memajukan bangsa. Peran perguruan tinggi untuk membentuk entrepreneur pada mahasiswanya sehingga kelak menjadi lulusan yang aktif, produktif dan pencetak lapangan kerja dan bukan pencari kerja.

\section{REFERENSI}

[1] Abu Marlo, 2013, Entrepreneurship Hukum Langit, , Jakarta: Gramedia Pustaka Utama.

[2] Agung Wahyu Handaru,2015. "Karakteristik Entrepreneur Melalui Multiple Diskriminan Analisis (Studi Pada Etnis Tionghoa, Jawa dan Minang di Bekasi Utara)"Jakarta: Jurnal Riset

[3] Antoni, 2014. "Muslim Entrepreneurship: Membangun Muslimpreneurs Characteristics

[4] Bangsa dan Masa Depan Anda. Jakarta: Elex Media Computindo

[5] Basrowi, 2014. Kewirausahaan untuk Perguruan Tinggi, Bogor : Ghalia Indonesia.

[6] Ciputra. (2009). Ciputra Quantum Leap: Entrepreneurship Mengubah Masa Depan

[7] Danang Sunyoto, Kewirausahaan Untuk Kesehatan, Yogyakarta :, Nuha Medika.
[8] Dengan Pendekatan Knowladge Based Economy”, Lombok Barat : El-Hikam.

[9] Donald Rutherford, Dictionary of Economics, London : Routledge.

[10] Friday O. Okpara,2007. "The Value of Creativity and Innovation in Entrepreneurship",

[11] Hannah Orwa Bula, 2012."Evolution and Theories of Entrepreneurship: A Critical Review onthe Kenyan Perspective", International Journal of Business and Commerce, Lahore

[12] https://www.depokpos.com/2018/01/entreprene ur-mahasiswa-satu-langkah-atasipengangguran/

[13] Jerussalem Adam. 2010" Membentuk Karakter Entrepreneur Mahasiswa Dalam Rangka Menyiapkan Lulusan Pencetak Lapangan Kerja. Prosiding Seminar Nasional PTBB. Yokyakarta

[14] Journal of Asia Entrepreneurship and Sustainability, Rossi Smith Academic Publishing, Oxford,

[15] Kasmir, 2013. Kewirausahaan, Jakarta : Raja Grafindo Persada.

[16] Manajemen Sains Indonesia (JRMSI). Suryana, 2013. Kewirausahaan: Kiat dan Proses Menuju Sukses, Jakarta: Salemba Empat.

[17] Moloeng, Lexy J. 2013. Metodologi Penelitian Kualitatif. Bandung: PT. Remaja Rosdakarya. Harsono. 2016. Etnografi Pendidikan: Sebagai Desain Penelitian Kualitatif. Surakarta: Universitas Muhammadiyah Surakarta

[18] Sugiyono. 2017. Metode Penelitian Pendidikan Pendekatan Kuantitatif, Kualitatif, dan R\&D. Bandung: Alfabeta 